\title{
SKRINING FITOKIMIA EKSTRAK CARICA PAPAYA RADIX, PIPER ORNATUM FOLIUM DAN NEPHELIUM LAPPACEUM SEMEN ASAL KALIMANTAN SELATAN
}

\author{
Phytochemical Screening of Carica papaya radix, Piper ornatum folium \\ and Nephelium lappaceum semen Extraxt from South Kalimantan
}

\author{
Muhammad Zaini ${ }^{1}$, Vivi Shofia ${ }^{2}$ \\ ${ }^{1}$ Program Studi D-III Farmasi Politeknik Unggulan Kalimantan \\ ${ }^{2}$ Program Studi D-III Analis Kesehatan Politeknik Unggulan Kalimantan
}

Email: zaini@polanka.ac.id

\begin{abstract}
Diabetes Mellitus was a disease with a high prevalence and was ranked in the top 10 in the world including in Indonesia. The big problem facing the health world today was Diabetes Mellitus cannot be completely cured with conventional antihyperglycemic drugs. Research needs to be done in terms of tracing the potential of natural materials commonly used by Kalimantan people based on phytochemical screening of some plants that are empirically used as antidiabetic namely Carica papaya radix (CPR), Nephelium lappaceum semen (NLS) and Piper ornatum folium (POF). Medicinal plants obtained were extracted maceration and identified groups of compounds and their chromatographic profiles. These research activities included: 1) Plant sample collection, 2) Making test simplicia, 3) Making plant ethanol extract, 4) Qualitative test of plant chemical content, and 5) Thin layer chromatography identification.

The results of the study were selected and tested on 3 extracts namely Carica papaya radix, Nephelium lappaceum semen and Piper ornatum folium. Carica papaya radix extract was thought to contain alkaloid compounds (Rf: 0.53), saponins (Rf: 0.93), flavonoids (Rf: 0.38; 0.75 ) and tannins (Rf: $0.52 ; 0.88$ ). Piper ornatum folium extract is thought to contain saponin compounds (Rf: 0.89), steroids (Rf: 0.20; 0.42) and tannins (Rf: 0.52; 0.71;0.85). Nephelium lappaceum semen extract showed positive results on the presence of alkaloid compounds (Rf: 0.65; 0.82), flavonoids (Rf: 0.83) and tannins (Rf: 0.79; 0.92).
\end{abstract}

\section{Keywords : Diabetes Mellitus, Antidiabetic, Extract, Thin Layer Chromatography}

\begin{abstract}
ABSTRAK
Diabetes Mellitus merupakan penyakit dengan prevalensi tinggi peringkat 10 besar di dunia termasuk di Indonesia. Permasalahan besar yang dihadapi dunia kesehatan adalah Diabetes Mellitus tidak bisa disembuhkan secara total dengan obat antihiperglikemik konvensional. Penelitian perlu dilakukan dalam hal menelusuri potensi bahan alam yang biasa digunakan masyarakat Kalimantan berdasarkan skrining fitokimia dari beberapa tumbuhan yang secara empiris digunakan sebagai antidiabetes yaitu Carica papaya radix (CPR), Nephelium lappaceum semen (NLS) dan Piper ornatum folium (POF). Tumbuhan obat yang diperoleh dilakukan ekstraksi maserasi dan diidentifikasi golongan senyawa dan profil kromatografinya.Kegiatan penelitian meliputi: 1) Pengambilan sampel tumbuhan,2) Pembuatan simplisia uji, 3) Pembuatan ekstrak etanol tumbuhan, 4) Uji kualitatif kandungan kimia tumbuhan, dan 5) Identifikasi secara kromatografi lapis tipis.

Hasil dari penelitian dipilih dan dilakukan pengujian terhadap 3 ekstrak yaitu Carica papaya radix, Nephelium lappaceum semen dan Piper ornatum folium. Ekstrak Carica papaya radix diduga mengandung senyawa alkaloid ( $R f: 0,53)$, saponin ( $R f: 0,93)$, flavonoid (Rf : 0,38;
\end{abstract}


$0,75)$ dan tanin (Rf : 0,$52 ; 0,88)$. Ekstrak Piper ornatum folium diduga mengandung senyawa saponin (Rf : 0,89), steroid (Rf:0,20;0,42) dan tanin (Rf : 0,52;0,71;0,85). Ekstrak Nephelium lappaceum semen menunjukkan hasil positif terhadap keberadaan senyawa alkaloid (Rf : 0,$65 ; 0,82)$, flavonoid $(\mathrm{Rf}: 0,83)$ dan tanin $(\mathrm{Rf}: 0,79 ; 0,92)$.

\section{Kata kunci : Diabetes Mellitus, antidiabetes, ekstrak, kromatografi lapis tipis}

\section{PENDAHULUAN}

Prospek pengembangan tumbuhan obat sebagai obat tradisional sangat cerah pada masa mendatang, ditinjau dari berbagai faktor penyokong.Faktor penyokong tersebut, yang pertama adalah tersedianya sumber kekayaan alam Indonesia dengan keanekaragaman hayati terbesar kedua di dunia. Faktor kedua ialah adanya sejarah pengobatan tradisional yang telah dikenal lama oleh nenek moyang dan diamalkan secara turun temurun sehingga menjadi warisan budaya bangsa, ketiga isu global "back to nature" sehingga meningkatkan pasar produk herbal termasuk Indonesia, dan terakhir yaitu krisis moneter yang menyebabkan pengobatan tradisional menjadi pilihan utama bagi sebagian besar masyarakat, sehingga perlu dilakukan pengembangan berbagai tumbuhan obat sebagai alternatif pengobatan lain bagi masyarakat kalangan menengah kebawah khususnya (Katno \& Pramono, 2002).

Pulau Kalimantan kaya akan sumber daya hayati berupa hutan tropis yang masih belum banyak dimanfaatkan dalam hal pengembangan obat. Potensi alam Kalimantan yang begitu besar dapat memberikan peluang untuk eskplorasi tumbuhan obat untuk menangani berbagai macam penyakit yang ada. Dewasa ini, perkembangan penyakit mulai menunjukkan kewaspadaan sebagaimanadata yang diperoleh dari halaman Kementerian Kesehatan Republik Indonesia menyebutkan NCD World Health Organization (WHO) tahun 2010 menyebutkan bahwa Penyakit Tidak Menular (PTM) merupakan penyebab $60 \%$ kematian semua umur di dunia. Diabetes mellitus menempati peringkat ke-6 sebagai penyakit yang berkontribusi dalam kematian di dunia. Sekitar 1,3 juta orang meninggal akibat diabetes dan $4 \%$ meninggal sebelum usia 70 tahun. Diabetes mellitus diperkiarakan pada tahun 2030 ke-7 penyebab kematian dunia.dan di Indonesiadiperikarakan tahun 2030 akan memiliki penderita Diabetes mellitus sebanyak 21,3 juta jiwa (Kemenkes RI, 2013).

Angka kejadian Diabetes mellitus yang tinggi memberikan gambaran bahwa perlunya mencari obat alternatif yang dapat menyembuhkan kejadian Diabetes Mellitus, mengingat sampai saat ini penggunaan obat antidiabetes konvensional belum mampu menangani kasus Diabetes Mellitus hingga tuntas.Program studi Farmasi Politeknik Unggulan Kalimantan melalui Diabetic Research Center (DRC) berupaya mengembangkan obat bahan alam antidiabetes dalam upaya menambah khazanah dan referesnsi obat antidiabetes alternatif untuk menangani masalah Diabetes Mellitus. Penelusuran obat antidiabetes berbasis bahan alam dapat diakukan dengan melakukan inventarisasi dan skrining fitokimia guna memperoleh data kandungan golongan senyawa yang berpotensi sebagai obat antidiabetes.

Penelitian ini dilaksanakan dengan mendata obat antidiabetes dari bahan alam yang secara empiris terbukti dapat menangani Diabetes Mellitus masyarakat Kalimantan Selatan yaitu Carica papaya radix (CPR), Nephelium lappaceum semen (NLS) dan Piper ornatum folium (POF). Sampel tersebut dilakukan analisa kualitatif golongan senyawa kimia yang berpotensi antidiabetes dan dilengkapi dengan profil kromatografi lapis tipisnya. Hasil dari penelitian ini diharapkan mendapatkan kejelasan kandungan kimia yang ada pada 
tumbuhan yang biasa dikonsumsi oleh masyarakat Kalimantan Selatan sebagai obat Diabetes Mellitus. Kandungan kimia dan profil kromatografi tersebut dapat menjadi referensi bagi peneliti bahan alam untuk langkah selanjutnya yaitu dasar melakukan uji farmakologi (preklinik) dan isolasi senyawa yang memiliki potensi besar untuk dikembangankan menjadi kandidat obat antidiabetes.

\section{METODE PENELITIAN}

\section{Bahan}

Bahan-bahan yang digunakan dalam penelitian ini yaitu Carica papaya radix, Nephelium lappaceum semen dan Piper ornatum folium, Aquadest, Etanol $70 \%$, $\mathrm{HCl} 2 \mathrm{~N}$, Serbuk Logam Mg, Besi (III) ammonium sulfat, Larutan $\mathrm{FeCl}_{3}$, Pereaksi Mayer LP, Amonia pekat $27 \%$, Kloroform, Natrium sulfat anhidrat, $\mathrm{H}_{2} \mathrm{SO}_{4} 2 \mathrm{~N}$, Pereaksi dragendorff, Pereaksi Lieberman-burchard, $n$-heksana, Etil asetat dan Metanol.

\section{Alat}

Alat-alat yang digunakan adalah beaker glass (pyrex), timbangan analitik (Ohaus), bejana maserasi, Vacum Rotary Evaporator, Waterbath, Oven, cawan porselin, mortir dan stamper, plat KLT, chamber, pipet tetes, pipet volume dan pipa kapiler.

\section{Pengolahan Simplisa}

Sampel penelitian ini adalah tumbuhan obat yang berasal dari Kalimantan Selatan yang secara empiris/pengalaman memiliki khasiat sebagai antidiabetes. Pengambilan sampel berdasarkan informasi masyarakat yang diperoleh yaitu terdapat tiga tumbuhan yang biasa digunakan sebagai antidiabetes yaitu Carica papaya radix (CPR), Piper ornatum folium (POF) dan Nephelium lappaceum semen (NLS). Seluruh sampel diperoleh dari Kalimantan Selatan.

\section{Ekstraksi}

Masing-masing simplisia yang sudah dibuat serbuk ditimbang sejumlah yang diperlukan, kemudian ditempatkandalam wadahtertutupdengan pelarut etanol 70 \%hingga serbuk terendam dan pelarut berada $2 \mathrm{~cm}$ di atas sampel. Proses maserasi dilakukan padasuhu kamardalam jangka waktuminimal 3haridengan sesekali pengadukkan hingga seluruh komponen kimianya terlarut. Remaserasi dilakukan dengan penambahan pelarut baru setelah dilakukan penyaringan terhadap maserat sebelumnya. Filtrat kemudian diuapkan menggunakan rotary evaporator suhu $60 \mathrm{oC}$ dan waterbath suhu $70 \mathrm{oC}$ hinggadiperoleh ekstrak dengan bobot tetap yang ditandai dengan bobot ekstrak tidak berubah dalam 3 kali penimbangan (Handa, 2008). Penyimpanan ekstrak memerlukankondisi khusus untuk kelembaban dan suhu atau perlindungan terhadap cahaya.Langkah yang sesuai hendaklah diambil untuk memastikan hal tersebut (BPOM RI, 2011).

\section{Uji Kualitatif Kandungan Kimia}

a. Reaksi identifikasi terhadap saponin

Masukkan sebanyak 0,5 gekstrak etanol tumbuhan obat dalam tabung reaksi, ditambahkan $10 \mathrm{~mL}$ air panas, didinginkan dan dikocok selama 10 detik. Saponin ditandai dengan adanya buih yang mantap selama 10 menit setinggi $1-10 \mathrm{~cm}$. Penambahan asam klorida $2 \mathrm{~N}$ buih tidak hilang (Depkes RI, 1995).

b. Reaksi identifikasi terhadap flavonoid 
Volume 2 No. 1 (April, 2020)

Masukkan sebanyak $2 \mathrm{~mL}$ ekstrak etanol tumbuhan obat dalam tabung reaksi lalu ditambah 10 tetes $\mathrm{HCl}$ pekat dan 0,1g serbuk logam magnesium. Flavonoid ditandai dengan adanya warna merahjinggahingga merah ungu (Depkes RI, 1995). 
c. Reaksi identifikasi terhadap tanin

Cara 1 :

Ekstrak etanol tumbuhan obat ditambahkan dengan larutan besi (III) amonium sulfat $\mathrm{P}$ yang telah diencerkan 5 kali. Bila terbentuk warna hijau atau biru hingga hitam menunjukkan adanya tanin (Depkes RI, 1979).

Cara 2 :

Ekstrak etanol tumbuhan obat ditambahkan dengan larutan $\mathrm{FeCl} 3$ menghasilkan warna hijau kehitaman untuk golongan tanin terkondensasi dan biru kehitaman untuk tanin terhidrolisis (Widowati, 2006).

d. Reaksi identifikasi terhadap alkaloid

Cara 1:

Masukkan sebanyak $0,5 \mathrm{~g}$ ekstrak dalam cawan porselin, ditambahkan dengan $1 \mathrm{~mL}$ asam klorida $2 \mathrm{~N}$ dan $9 \mathrm{~mL}$ air, panaskan diatas penangas air selama 2 menit, dinginkan dan saring. Pindahkan 3 tetes filtrat pada kaca arloji, ditambahkan pereaksi Mayer LP terbentuk endapan menggumpal berwarna putih atau kuning yang larut dalam metanol $P$ menunjukkan adanya alkaloid (Depkes RI, 1995).

Cara 2 :

Ekstrak etanol diekstraksi dengan kloroform beramonia yang dibuat dari $1 \mathrm{~mL}$ amonia pekat $27 \%$ ditambah $250 \mathrm{~mL}$ kloroform dan 2,5 g natrium sulfat anhidrat dan disaring. Filtrat dari hasil ekstraksi tersebut ditambah $1 \mathrm{~mL} \mathrm{H} 2 \mathrm{SO} 42 \mathrm{~N}$, dikocok hingga terbentuk 2 lapisan.Lapisan bagian atas diambil, ditambah pereaksi dragendorff. Alkaloid ditandai dengan adanya endapan cokelat kemerahan (Kristanti et al.,2008)

e. Reaksi identifikasi terhadap steroid

Ekstrak 0,25 mg ditambahkan dengan 2-3 $\mathrm{mL}$ kloroform dan ditambahkan dengan Lieberman-burchard ( $5 \mathrm{~mL}$ asam asetat anhidrat ditambahkan $\mathrm{H} 2 \mathrm{SO} 45 \mathrm{~mL}$ dan etanol $50 \mathrm{~mL}$ ). Positif mengandung steroid jika berwarna biru-hijau (Autherhoff \& Kovar, 2002).

\section{Identifikasi Kromatografi Lapis Tipis}

Tahapan yang dilaksanakan yaitu :

a. Melarutkan ekstrak tumbuhan dengan metanol dalam vial.

b. Menotolkan ekstrak tumbuhan yang telah diencerkan di atas plat KLT hingga terbentuk noda.

c. Memasukkan ke dalam chamber yang berisi eluen yang telah dijenuhkan.

d. Mengeluarkan plat KLT hasil penotolan dari chamber setelah eluen yang menaik mendekati garis batas atas sebesar $0,5 \mathrm{~cm}$.

e. Mengamati noda yang terbentuk di bawah sinar UV dengan $\lambda 254$ dan $366 \mathrm{~nm}$.

f. Menggambar hasil yang terbentuk.

g. Menyemprotkan plat KLT yang ada nodanya dengan pereaksi semprot dengan totolan utama berada di atas, setelah diamati dengan sinar UV.

h. Memanaskan di atas bunsen sehingga noda atau plot terlihat jelas.

i. Mengamati kembali noda yang terbentuk di bawah sinar UV dengan $\lambda$ sebesar 254 dan $366 \mathrm{~nm}$ dan menggambar hasilnya.

j. Menghitung nilai Rf. 


\section{HASIL DAN PEMBAHASAN}

\section{Hasil Ekstraksi}

Metode ekstraksi yang digunakan pada penelitian ini adalah ekstraksi dingin yaitu secara maserasi. Sampel CPR, POF dan NLS masing-masing dibuat serbuk menggunakan blender. Serbuk masing-masing sampel ditimbang sebanyak 100 gram dan dimasukkan dalam wadah maserasi. Ekstraksi dilakukan selama 3 hari menggunakan pelarut etanol $70 \%$. Masing-masing sampel menggunakan pelarut sebanyak 1 liter. Ekstrak kemudian dikentalkan dengan penguapan waterbath sehingga diperoleh ekstrak kental. Nilai persentase kandungan kimia (\% rendemen) yang berhasil terekstraksi dapat dilihat pada tabel 1.

Tabel 1. Hasil perhitungan \% rendemen ekstrak

\begin{tabular}{|c|c|c|c|c|}
\hline No. & Nama Tumbuhan & Bobot simplisia (gr) & Bobot ekstrak (gr) & \% Rendemen (\%) \\
\hline 1. & $\begin{array}{l}\text { CPR } \\
\end{array}$ & 100 & 3,80 & 3,80 \\
\hline 2. & POF & 100 & 7,20 & 7,20 \\
\hline 3. & NLS & 100 & 3,10 & 3,10 \\
\hline
\end{tabular}

\section{Hasil Uji Identifikasi Kimia}

Hasil uji identifikasi kimia ekstrak CPR, POF dan NLS terhadap keberadaan Alkaloid, Saponin, Steroid, Flavonoid dan Tanin ditampilkan pada tabel 2.

Tabel 2. Hasil uji identifikasi kandungan kimia ekstrak CPR, POF dan NLS

\begin{tabular}{ccccc}
\hline No. & \multirow{2}{*}{ Identifikasi } & \multicolumn{4}{c}{ Ekstak } \\
\cline { 3 - 5 } & Alkaloid & Akar papaya & Sirih hutan & Biji rambutan \\
\hline 1 & Saponin & + & - & + \\
\hline 2 & Steroid & + & + & - \\
\hline 3 & Flavonoid & - & + & - \\
\hline 4 & Tanin & + & - & + \\
\hline 5 & + & + & + \\
\hline
\end{tabular}

\section{Hasil Kromatografi Lapis Tipis}

Profil kromatografi lapis tipis (KLT) digunakan sebagai data untuk mempertegas kandungan kimia yang terdapat pada masing-masing ekstrak tumbuhan yang berkhasiat sebagai antidiabetes. Proses KLT dilakukan dengan berbagai pengujian orientasi untuk menentukan komposisi eluen yang dapat memisahkan komponen kimia eksrak dengan baik. Orientasi dilakukan untuk mencari komposisi eluen yang tepat untuk memisahkan dan mendeteksi keberadaan golongan senyawa masing-masing ekstrak berdasarkan uji kualitatif. Hasil orientasi diperoleh komposisi eluen n-heksan : etil asetat (5:5) untuk golongan alkaloid dan steroid, kloroform : methanol : air (10:7:4) untuk saponin dan $n-$ butanol : asam asetat : air (4:1:5) untuk golongan tanin dan flavonoid. Noda yang diperoleh dari masing-masing plat KLT kemudian dihitung nilai $\mathrm{Rf}$ dan di deteksi menggunakan pereaksi semprot. Hasil KLT terhadap masing-masing ekstrak sampel didapatkan nilai Rf sebagaiman pada tabel 3 . 
Tabel 3. Profil KLT Ekstrak Sampel Tumbuhan

\begin{tabular}{|c|c|c|c|c|}
\hline No. & Ekstrak Tumbuhan & Uji & Eluen & $R f$ \\
\hline \multirow{4}{*}{1} & \multirow{4}{*}{ CPR } & Alkaloid & n-hex : EtoAc (5:5) & 0,53 \\
\hline & & Saponin & kloroform : $\mathrm{MeOH}:$ Air (10:7:4) & 0,93 \\
\hline & & Flavonoid & n-Butanol : As. Asetat : Air (4:1:5) & $\begin{array}{l}0,38 \\
0,75\end{array}$ \\
\hline & & Tanin & n-Butanol : As. Asetat : Air (4:1:5) & $\begin{array}{l}0,52 \\
0,71 \\
0,85\end{array}$ \\
\hline \multirow{3}{*}{2} & \multirow{3}{*}{ POF } & Saponin & kloroform : $\mathrm{MeOH}:$ Air (10:7:4) & 0,89 \\
\hline & & Steroid & n-hex : EtoAc (5:5) & $\begin{array}{l}0,05 \\
0,20 \\
0,42 \\
0,65 \\
0,76\end{array}$ \\
\hline & & Tanin & n-Butanol : As. Asetat : Air ( $4: 1: 5)$ & \\
\hline \multirow{3}{*}{3} & \multirow{3}{*}{ NLS } & Alkaloid & n-hex : EtoAc (5:5) & $\begin{array}{l}0,65 \\
0,82\end{array}$ \\
\hline & & Flavonoid & n-Butanol : As. Asetat : Air (4:1:5) & 0,82 \\
\hline & & Tanin & n-Butanol : As. Asetat : Air (4:1:5) & $\begin{array}{l}0,79 \\
0,92\end{array}$ \\
\hline
\end{tabular}

Pereaksi semprot digunakan untuk mempertegas dugaan kandungan kimia dalam sampel ekstrak tumbuhan. Hasil dari pemberian pereaksi semprot pada noda KLT masingmasing ekstrak tumbuhan yang menunjukkan hasil positif dapat dilihat pada tabel 4 .

Tabel 4. Hasil uji KLT ekstak

\begin{tabular}{|c|c|c|c|c|c|c|c|}
\hline \multirow{2}{*}{ No. } & \multirow{2}{*}{$\begin{array}{c}\text { Ekstrak } \\
\text { Tumbuhan }\end{array}$} & \multirow{2}{*}{ Kandungan Kimia } & \multirow{2}{*}{$\mathrm{Rf}$} & \multicolumn{3}{|c|}{ Warna } & \multirow{2}{*}{ Ket } \\
\hline & & & & Reaksi Semprot & UV $254 \mathrm{~nm}$ & UV 366 nm & \\
\hline \multirow{6}{*}{1} & \multirow{6}{*}{ CPR } & Alkaloid & 0,53 & Jingga & Jingga & Coklat & + \\
\hline & & Saponin & 0,93 & Hijau kuning & Kuning & Gelap & + \\
\hline & & & 0,38 & Biru-hitam & Ungu & Ungu & + \\
\hline & & FlavonoId & 0,75 & Biru-hitam & ungu & Ungu & \\
\hline & & & 0,52 & Hijau muda & Hijau muda & Ungu & \\
\hline & & Tanin & 0,88 & Hijau muda & Hijau-biru & Ungu & + \\
\hline \multirow{9}{*}{2} & \multirow{9}{*}{ POF } & Saponin & 0,89 & Hijau kuning & Kuning & Gelap & + \\
\hline & & \multirow{5}{*}{ Steroid } & 0,05 & Hijau & - & Gelap & - \\
\hline & & & 0,20 & Biru tua & Biru & Gelap & + \\
\hline & & & 0,42 & Biru tua & Biru & Gelap & + \\
\hline & & & 0,65 & Hijau & - & Gelap & - \\
\hline & & & 0,76 & Hijau & - & Gelap & - \\
\hline & & \multirow{3}{*}{ Tanin } & 0,52 & Hijau muda & Coklat & - & - \\
\hline & & & 0,71 & Hijau tua & Hijau tua & Ungu & + \\
\hline & & & 0,85 & Hijau muda & Hijau muda & Ungu & + \\
\hline \multirow{5}{*}{3} & \multirow{5}{*}{ NLS } & \multirow{2}{*}{ Alkaloid } & 0,65 & Jingga & Jingga & Coklat & + \\
\hline & & & 0,82 & Jingga & Jingga & Coklat & + \\
\hline & & Flavonoid & 0,83 & Biru-hitam & Ungu & Ungu & + \\
\hline & & \multirow{2}{*}{ Tanin } & 0,79 & Hijau muda & Hijau muda & Ungu-merah & + \\
\hline & & & 0,92 & Hijau muda & Hijau muda & Ungu-merah & + \\
\hline
\end{tabular}

Keterangan: Alkaloid : Pereaksi Dragendorf

Saponin : Pereaksi Lieberman Burchard

Steroid : Pereaksi Lieberman Burchard

Flavonoid : Pereaksi $\mathrm{NH}_{3}$

Tanin : Pereaksi $\mathrm{FeCl}_{3}$

Golongan alkaloid, saponin dan flavonoid diketahui dapat bersifat antidiabetes melalui mekanisme penghambatan enzim $\alpha$-glukosidase (Sari, 2010). Tanin merupakan senyawa antioksidan memiliki potensi sebagai antidiabetes yang mampu mencegah terjadinya oksidasi glukosa dalam darah (Rosiyana, 2012). Diketahui bahwa senyawa asam tanat (tanin) memiliki aktivitas antioksidan serta mempunyai efek sebagai antidiabetes 
(Hagerman, 2002). Steroid merupakan bagian dari struktur aglikon dari saponin, dimana steroid memiliki efek menstimulasi keluarnya insulin (Sediarso et al, 2008).

Alkaloid adalah golongan senyawa kimia yang bersifat basa, mengandung satu atau lebih atom nitrogen biasanya dalam gabungan berbentuk siklik, serta dapat dideteksi dengan cara pengendapan menggunakan pereaksi Mayer, Dragendorf dan Bourchard (Harborn, 1987). Pada uji alkaloid dengan pereaksi Dragendorff, nitrogen digunakan untuk membentuk ikatan kovalen koordinat dengan $\mathrm{K}^{+}$yang merupakan ion logam (Miroslav, 1971). Dalam pengujian ini sampel tumbuhan diuji dengan perekasi Dragendorf yang menunjukkan hasil positif pada ekstrak akar pepaya dan biji rambutan. Reaksi pada uji Dragendorff ditunjukkan pada gambar 1.

$$
\text { Kalium tetraiodobismutat }
$$

Gambar 1. Reaksi uji Dragendorff

Saponin adalah glikosida terpen yang merupakan senyawa aktif permukaan dan dapat menimbulkan busa jika dikocok dengan air. Reaksi hidrolisis saponin ditunjukkan pada gambar 2 .

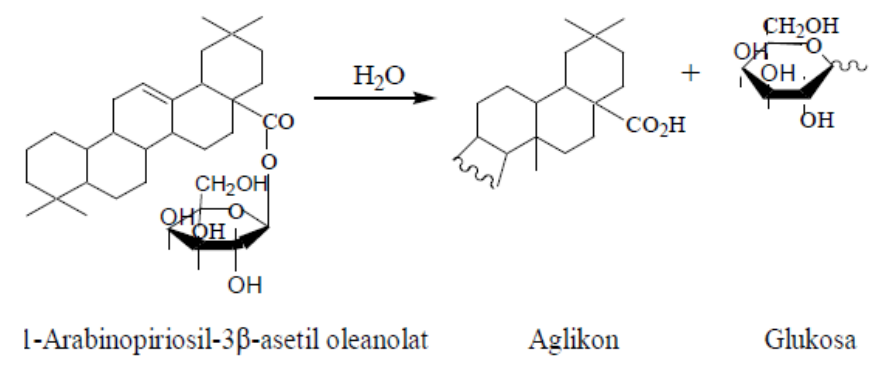

Gambar 2. Reaksi hidrolisis saponin

Steroid merupakan suatu hormone yang terdapat di dalam tumbuhan. Steroid diidentifikasi dengan pereaksi Lieberman-Burchard yaitu mereaksikan dengan asam asetat anhidrat dan asam sulfat pekat di dalam etanol. Hasil positif ditandai dengan adanya warna hijau (Harborn, 1987). Pada pengujian ektrak sampel diperoleh hasil positif pada ekstrak daun sirih hutan. Reaksi pada steroid diprediksi seperti pada gambar 3. 

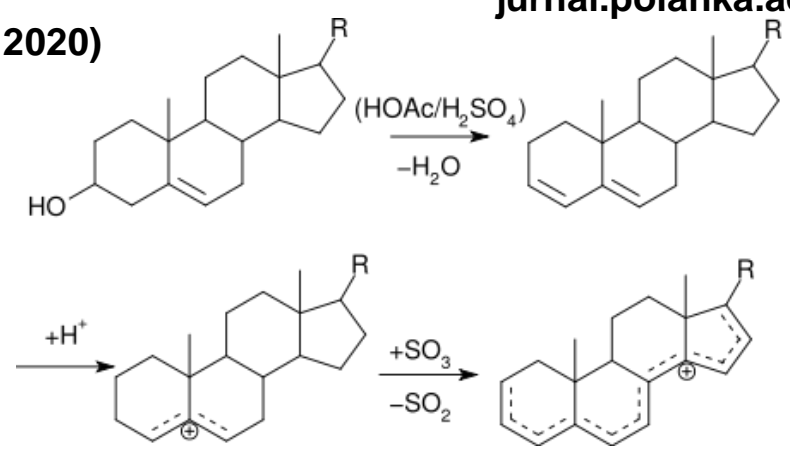

Gambar 3. Reaksi steroid

Flavonoid terdapat di dalam tumbuhan sebagai glikosida dan aglikon flavonoid. Pendeteksian adanya flavonoid dilakukan dengan mereaksikannya dengan larutan besi (III) klorida $1 \%$ dalam air atau etanol yang menimbulkan warna hijau atau hitam kuat (Harborn, 1987). Pada pengujian diperoleh akar pepaya dan biji rambutan positif terhadap keberadaan flavonoid. Reaksi terhadap flavonoid diprediksi seperti pada gambar 4.

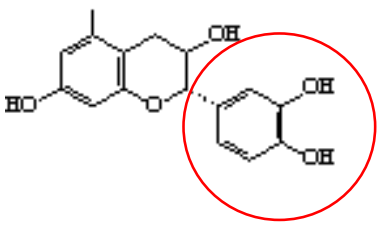

catechin
3<smiles>Oc1ccccc1O</smiles><smiles>CCC(CC)[C@H](CC)Oc1ccccc1OC</smiles>

Gambar 4. Reaksi flavonoid (katekin)

Tanin merupakan senyawa yang umum terdapat dalam tumbuhan yang mana tanin memiliki gugus fenol, rasa sepat dan mampu menyamak kulit karena kemampuannya menyambung-silang protein membentuk kopolimer mantap yang tak larut ait. Tanin diidentifikasi dengan $\mathrm{FeCl}_{3}$ membentuk warna hijau atau hitam. Pada pengujian seluruh sampel ekstrak mengandung tanin (Harborn, 1987). Reaksi tanin dan $\mathrm{FeCl}_{3}$ diprediksi menurut reaksi pada gambar 5 .

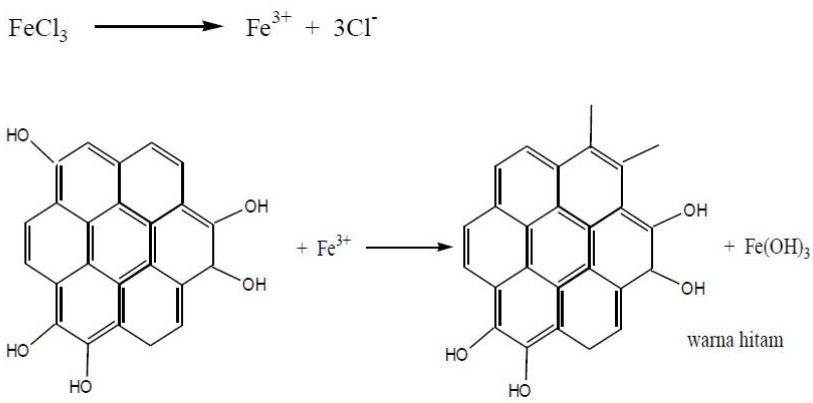

Gambar 5. Reaksi identifikasi tanin 
Uji identifikasi dengan kromatografi lapis tipis $(K L T)$ dilakukan untuk memastikan kandungan kimia yang terdapat di dalam sampel ekstrak. Tahapan KLT dilakukan terlebih dahulu dengan melarutkan masing-masing ekstrak dengan methanol proanalisis. Pada sistem kromatografi partisi seperti KLT digunakan dua fase yaitu fase diam dan fase gerak. Fase diam yang digunakan adalah plat KLT yang berisi komponen silica GF60. Fase gerak (eluen) merupakan komposisi dari perbandingan pelarut yang berfungsi sebagai pembawa kandungan aktif dari ekstrak dan terpisah menjadi noda. Perbandingan eluen diperoleh melalui hasil orientasi. Dasar pemilihan komposisi eluen adalah melalui studi literatur. Setelah eluen dibuat, selanjutnya dilakukan penjenuhan eluen pada chamber. Sampel masing-masing ekstrak ditotolkan pada plat KLT berukuran $7 \mathrm{~cm}$ dengan batas bawah $1 \mathrm{~cm}$ dan batas atas $0,5 \mathrm{~cm}$. Plat KLT masing-masing ekstrak dimasukkan ke dalam chamber berisi eluen dan dilakukan proses elusidasi dari batas bawah plat hingga mencapai batas atas. Orientasi awal dilakukan menggunakan eluen n-heksan : etil asetat yang mana pemisahan yang bagus diperoleh pada perbandingan $5: 5$. Eluen $n$-heksan dan etil asetat banyak digunakan untuk mendeteksi keberadaan jenis golongan alkaloid. Berdasarkan penyinaran dengan sinar UV 254 dan 366 nm diperoleh 2 noda pada ekstrak akar pepaya dan 1 noda pada ekstrak biji rambutan. Tahap selanjutnya adalah dengan reaksi penegasan melalui penyemprotan dengan pereaksi Dragendorf pada noda yang muncul yang mana jika mengandung alkaloid akan menimbulkan noda berwarna kuning/jingga. Hasil uji KLT dapat dilihat pada gambar 6.

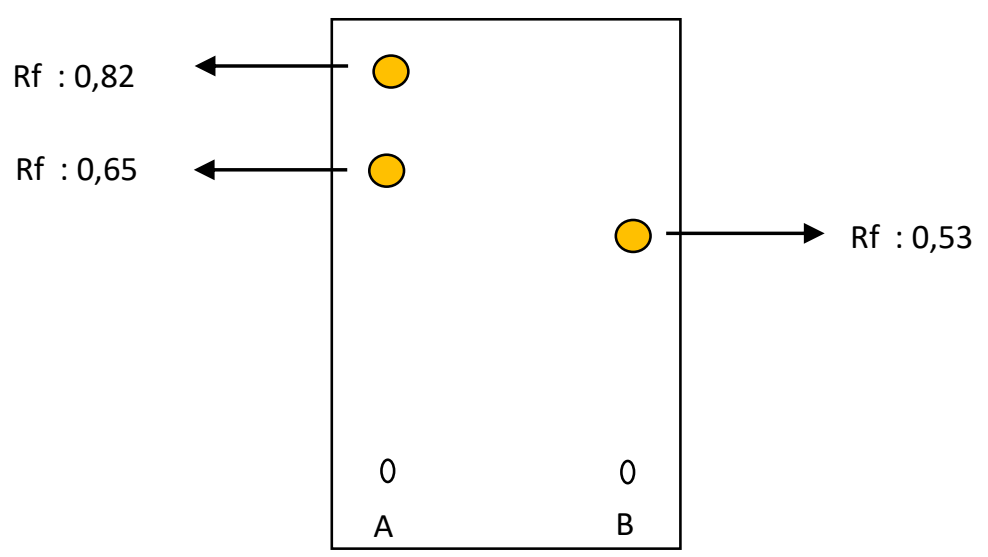

Gambar 6. Profil KLT eluen n-heksan : etil asetat (5:5) Pereaksi Dragendorf

Ket : A : ekstrak akar pepaya

B : ekstrak biji rambutan

Hasil KLT menggunakan eluen n-heksan : etil asetat (5:5) menunjukkan terdapat noda berwarna jingga pada penyemprotan dengan pereaksi Dreagendorf dengan nilai $\mathrm{Rf}:$ 0,82 dan $\mathrm{Rf}:$ 0,65. Ekstrak biji rambutan diperoleh 1 noda berwarna 
jingga dengan nilai Rf : 0,53. Berdasarkan penyinaran dengan UV 254 noda pada plat terlihat berwarna jingga dan kecoklatan pada UV $366 \mathrm{~nm}$, dari hasil tersebut diprediksi terdapat kandungan alkaloid pada ekstrak akar pepaya dan biji rambutan.

Eluen n-heksan : etil asetat juga dapat digunakan untuk deteksi keberadaan steroid, dimana noda akan berwarna biru tua dengan uv 254 dan $366 \mathrm{~nm}$ dan dengan pereaksi Lieberman-burchard akan nampak bercak noda berwarna biru tua yang tajam. Steroid terdeteksi pada ekstrak sirih hutan yang mana dengan eluen nheksan dan etil asetat $5: 5$ terdapat 5 noda pada $\mathrm{Rf}: 0,76 ; 0,65 ; 0,42 ; 0,20$ dan 0,05. Pada sinar UV 254 dan 366 hanya 2 noda yang terlihat berwarna biru yaitu pada $\mathrm{Rf}: 0,20$ dan 0,42 . Hal ini didukung oleh reaksi semprot menunjukkan warna biru pada dua noda tersebut. Sehingga, dapat diprediksi terdapat steroid pada ekstrak daun sirih hutan. Profil KLT dapat dilihat pada gambar 7 .

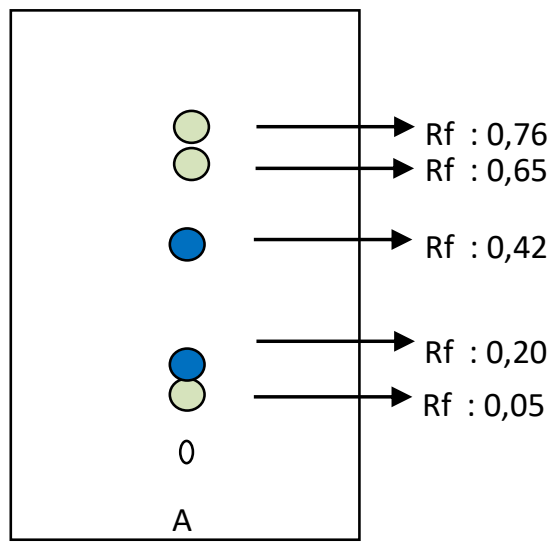

Gambar 7. Profil KLT eluen n-heksan : etil asetat (5:5) Pereaksi Lieberman-Burchard Ket : A : ekstrak daun sirih hutan

Eluen yang digunakan untuk identifikasi keberadaan saponin adalah menggunakan komposisi eluen kloroform : methanol : air dengan perbandingan 10 : $7: 4$. Komposisi tersebut dapat memisahkan dengan baik noda. Saponin terdeteksi sebagai noda berwarna kuning pada UV 254 nm dan gelap pada UV 366 nm. Ekstrak akar pepaya dan sirih hutan terdeteksi mengandung saponin berdasarkan uji busa. KLT terhadap kedua ekstrak tersebut didapatkan noda kuning dengan nilai Rf : 0,93 untuk ekstrak akar pepaya dan $\mathrm{Rf}$ : 0,89 untuk ekstrak daun sirih hutan. Deteksi noda menggunakan pereaksi semprot Lieberman Burchard diperoleh noda berwarna hijau kekuningan yang kemungkinan besar merupakan senyawa saponin. Hasil KLT untuk deteksi saponin dapat dilihat pada gambar 8 . 


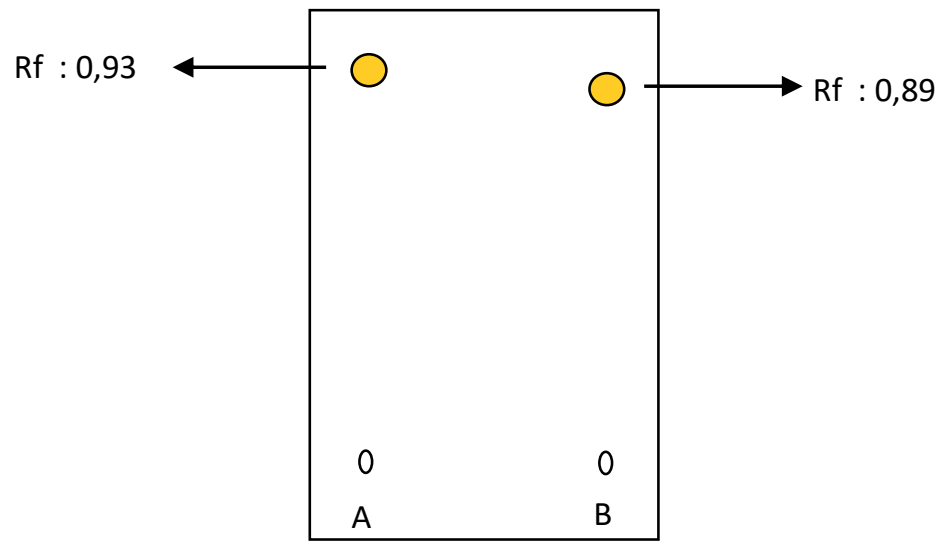

Gambar 8. Profil KLT eluen kloroform : methanol : air (10:7:4) Pereaksi Lieberman-Burchard

Ket : A : ekstrak akar pepaya

$B$ : ekstrak daun sirih hutan

Kandungan kimia flavonoid dan tanin juga terdeteksi keberadaannya pada uji kualitatif kandungan kimia ekstrak. Tanin terhidrolisis terdeteksi dengan warna hijau pekat pada ekstrak yang ditambahkan besi (III) klorida. Ketiga ekstrak yang diujikan positif mengandung senyawa tanin. Sedangkan flavonoid positif pada ekstrak akar pepaya dan biji rambutan. Eluen yang digunakan pada proses KLT adalah eluen polar yaitu n-butanol : asam asetat : air. Hasil analisa dengan metode $\mathrm{KLT}$ dengan pereaksi semprot $\mathrm{FeCl}_{3}$ noda akan berwarna hijau dan UV $254 \mathrm{~nm}$ berwarna hijau-biru. Flavonoid dengan $\mathrm{FeCl}_{3}$ akan berwarna biru-hitam dengan penampakan UV $254 \mathrm{~nm}$ berwarna ungu. Akar pepaya diprediksi mengandung tanin dari 2 noda hasil KLT pada Rf : 0,52 dan 0,88. Sirih hutan menunjukkan noda positif pada $\mathrm{Rf}: 0,71$ dan 0,85 sedangkan biji rambutan pada noda dengan nilai $\mathrm{Rf}: 0,79$ dan 0,92. Profil KLT deteksi tanin dapat dilihat pada gambar 9.

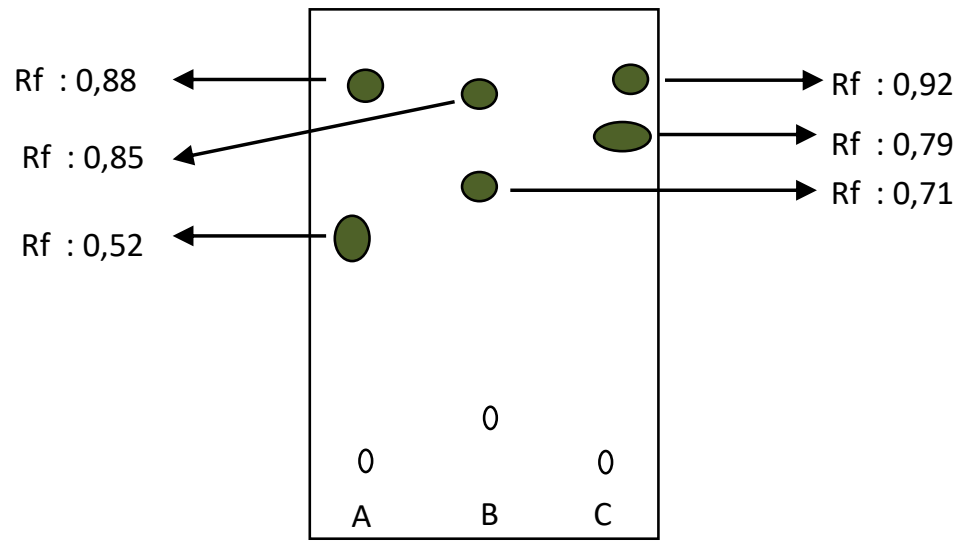

Gambar 9. Profil KLT eluen n-butanol : asam asetat : air (4:1:5) dengan Pereaksi $\mathrm{FeCl}_{3}$

Ket : A : ekstrak akar pepaya

$B$ : ekstrak daun sirih hutan

C : ekstrak biji rambutan 
Ekstrak akar pepaya dan biji rambutan diprediksi mengandung flavonoid berdasarkan reaksi $\mathrm{FeCl}_{3}$ dengan ekstrak pada uji kualitatif kandungan kimia. Keberadaan flavonoid diuji lebih lanjut menggunakan KLT dengan eluen $n$-butanol : asam asetat : air (4:1:5) diperoleh 2 noda pada ekstrak akar pepaya dengan nilai Rf : 0,38 dan 0,75. Sedangkan ekstrak biji rambutan menunjukkan keberadaan 1 noda dengan nilai $\mathrm{Rf}:$ 0,82. Pada penyemprotan dengan pereaksi $\mathrm{FeCl}_{3}$ diperoleh noda berwarna biru tua yang diduga merupakan suatu senyawa flavonoid. Profil KLT untuk uji tersebut dapat dilihat pada gambar 10.

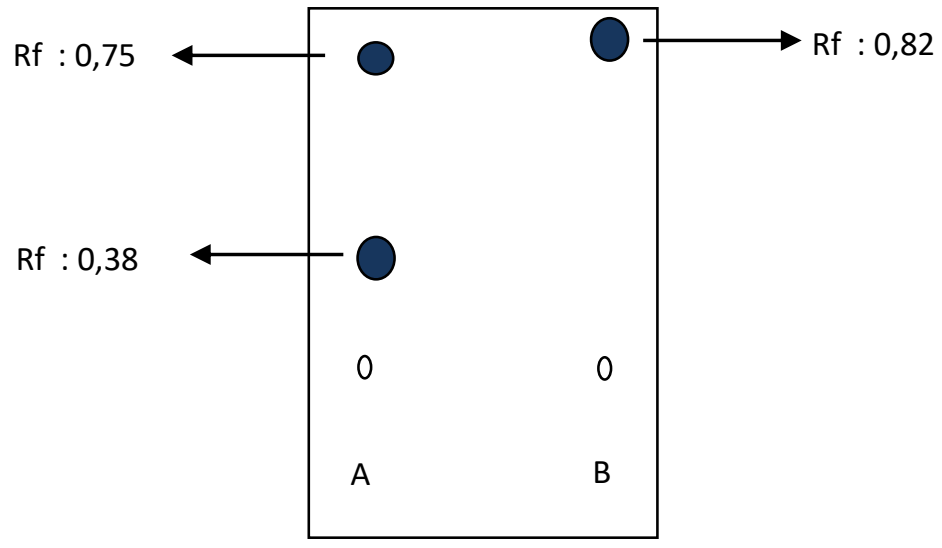

Gambar 10. Profil KLT eluen eluen n-butanol : asam asetat : air (4:1:5) dengan Pereaksi $\mathrm{FeCl}_{3}$

Ket : A : ekstrak akar pepaya

B : ekstrak biji rambutan

\section{KESIMPULAN}

Penapisan fitokimia yang terkandung dalam sampel tumbuhan antidiabetes ekstrak akar pepaya menunjukkan hasil positif terhadap keberadaan alkaloid, saponin, tanin dan flavonoid. Ekstrak daun sirih hutan positif terhadap saponin, tanin dan steroid. Sedangkan ekstrak biji rambutan menunjukkan reaksi positif terhadap alkaloid, tanin dan flavonoid. Ekstrak akar papaya diduga mengandung senyawa alkaloid (Rf : 0,53), saponin (Rf : 0,93), flavonoid ( $\mathrm{Rf}: 0,38 ; 0,75)$ dan tanin ( $\mathrm{Rf}: 0,52 ; 0,88)$. Ekstrak Sirih hutan diduga mengandung senyawa saponin ( $\mathrm{Rf}: 0,89$ ), steroid $(\mathrm{Rf}: 0,20 ; 0,42)$ dan tanin $(\mathrm{Rf}: 0,52 ; 0,71$ ; 0,85). Ekstrak biji rambutan menunjukkan hasil positif terhadap keberadaan senyawa alkaloid (Rf : 0,$65 ; 0,82)$, flavonoid (Rf: 0,83) dan tanin (Rf : 0,$79 ; 0,92)$.

\section{DAFTAR PUSTAKA}

Autherhoff, H \& K. Kovar. 2002. Identifikasi Obat. ITB, Bandung. Hal 9.

American Diabetes Association.2011.Diagnosis and Classification of Diabetes Mellitus. Diabetes Care.34: s62-9.

BPOM RI. 2011. Peraturan Kepala Badan Pengawas Obat dan Makanan Republik Indonesia Nomor Hk.03.1.23.06.11.5629 Tahun 2011 tentang Persyaratan Teknis Cara Pembuatan Obat Tradisional Yang Baik.Badan Pengawas Obat dan Makanan Republik Indonesia, Jakarta. Hal 2-11.

DepkesRI. 1979. Farmakope Indonesia. Edisi III. Departemen Kesehatan Republik Indonesia, Jakarta. Hal 28. 
DepkesRI. 1995. Materia Medika IndonesiaJilid VI. Cetakan Pertama. Departemen Kesehatan Republik Indonesia, Jakarta. Hal X , 146 , 333 , 336-337.

Dewi. 2007. Materi Pelatihan Profesional Tanaman Obat (Kelas Profesional). LembagaPendidikan Pengobatan Herba dan Alternatif Karyasari. Ciputat.

Endarwati. 2005. Tanaman Indonesia.ECG. Jakarta.

Handa, S.S. 2008. An Overview of Extraction Techniques for Medicinal and Aromatic Plants.Chapter I. International Center for Science an High Technology. Italy.

Hagerman AE. 2002. Tannin Handbook. Jurusan Kimia dan Biokimia. Universitas Miami. Miami.

Harborm, J.B, 1987. Metode Fitokimia Penentuan Cara Modern Menganalisis Tumbuhan.

Penerjemah Kosasih bPadmawinata dan Iwang Soediro. Bandung : ITB.

Katno \& S. Pramono.2002. Tingkat Manfaat dan Keamanan Tanaman Obat dan Obat Tradisional. Gadjah Mada University Press. Yogyakarta

Miroslav, V. 1971. Detection and Identification of Organic Compound. New York: Planum Publishing Corporation and SNTC Publishers of Technical Literatur

Kemenkes RI. Diabetes Melitus Penyebab Kematian Nomor 6 di Dunia: Kemenkes Tawarkan Solusi Cerdik Melalui Posbind. Diakses tanggal 12 maret 2016.

Rosiyana AN. 2012. Skripsi Aktivitas Antioksidan dan Penghambatan a-Glukosidase Ekstrak dan Nanopartikel Ekstrak Kulit Kayu Mahoni (Swietenia macrophylla King). Institut Pertanian Bogor.

Sari, D.R. 2010. Pemisahan Senyawa Alkaloid (Kafein) dari Daun Teh. Laporan Praktikum Tidak Diterbitkan: Jurusan Kimia Institut Teknologi Bandung. Bandung.

Saxena, N., P.N. Shrivastava \& R. C. Saxena. 2012. Preliminary Physico-Phytochemical Study of Stem Bark of (Alstonia Scholaris L.) R. BR. - A Medicinal Plant. International Journal of Pharmaceutical Sciences and Research, Vol. 3(4) : 1071-1075

Sediarso, H. Sunaryo dan N. Amalia. 2008. Efek Antidiabetes dan Identifikasi Senyawa Dominan dalam Fraksi Kloroform Herba Ciplukan (Physali angulate L). Universitas Muhammadiyah Prof. Dr. Hamka. Jakarta

Sulastri, Taty. 2009. Analisis Kadar Tanin Ekstrak Air dan Ekstrak Etanol pada Biji Pinang Sirih (Areca Catechu. L).Jurnal Chemica Vol. 10 Nomor 1, 59-63

Widowati, E. 2006.Pengaruh Lama Perendaman Dengan Larutan Kapur Tohor $\mathrm{Ca}(\mathrm{OH}) 2 \mathrm{Pada}$ Kulit Buah Manggis Terhadap Kualitas Kembang Gula Jelly. Skripsi. Fakultas Teknik, Universitas Negeri Semarang, Semarang. 